\title{
Minorities in Islam/Muslims as minorities
}

\author{
Michaelle Browers
}

Published online: 27 April 2014

(C) Springer Science+Business Media Dordrecht 2014

The author would like to thank the following Wake Forest University departments, programs, and offices for making the conference out of which these articles were drawn possible: the Middle East and South Asia Studies, the C.H. Richards Fund of the Department of Politics and International Affairs, the Center for International Studies, the Carswell Fund of the Department of Philosophy, the Humanities Institute, and the Provost's Global Affairs Funds. The author would further like to thank the editors of Contemporary Islam and the many anonymous reviewers whose comments and feedback contributed to the further development of these articles.

In October 2012, Wake Forest University brought together 25 scholars from across the globe and across the disciplines of religion, anthropology, politics, literature, and sociology for a 3-day conference entitled "Minorities in Islam/Muslims as Minorities." The conference theme was premised on bringing together two rich and burgeoning areas of inquiry that often seem to be working or thinking through their topic separately: one which aims to enrich our understanding of the experience of Muslims as minorities and another which examines the engagement of Muslims with minorities. The themes of this conference are central to Contemporary Islam, as it demonstrates the interaction between local and global in - and the dynamic character of-contemporary Islamic thought and practice. Some papers (such as Warren and Gilmore's) deal more with theory, others focus a bit more on practice (such as Leichman's), and some treat theory and practice in near equal measure (such as Shavit's and Burhani's). However, the four papers from that conference, published here for the first time, each speak in various ways to the intersection of Islamic thought and practice on the topic - as well as the ways in which Islamic thought and practice is today a translocal phenomenon, crossing boundaries of Sunni and Shi' $\mathrm{i}$, and expanding from the Middle East to Africa to Asia to Europe and beyond.

The status of Muslim minorities residing in non-Muslim contexts is not a new topic for Islamic thinkers. Abu-Salieh's study of "The Islamic Concept of Migration" demonstrates how such classical Islamic jurists such as Muhammad Ibn Idris al-Shafi'i (767-820) and Muwaffaq al-Din Ibn Qudama (1147-1223) both maintained that, in general, "Muslims living in dar al-harb [the land of war; land not governed by

\footnotetext{
M. Browers $(\bowtie)$

Wake Forest University, Winston-Salem, NC 27109, USA

e-mail: browerm@wfu.edu
} 
Muslims] must immigrate to dar al-Islam [the land of Islam]" while allowing various exceptions in cases of illness and hardship and for the purposes of engaging in jihad against infidels and missionary activity (da'wa) (1996: 43). However, the classical injunction for jurists to study the question with attention to its context and with consideration of its implications before offering an answer traditionally was undertaken with the notion of that the circumstances (migration) remained transitory. Some modern Muslim jurists are beginning to treat the situation of Muslim minorities as (exceptional) cases that require special consideration. The result is a growth in writings falling under the appellation of a "jurisprudence of minorities" (fiqh al-aqalliyyat).

Yusuf al-Qaradawi (1926-), a figure discussed at length in the articles by Warren and Gilmore and Shavit, garners considerable interest in this regard, as he is widely regarded as having popularized, if not coined, the concept of fiqh al-aqalliyyat, the main aims of which are to provide guidance for Muslims living in non-Muslim contexts in maintaining a life according to the shari ' $a$ while maintaining positive interactions with non-Muslims and to help them navigate the particular questions and struggles they encounter in the process (Al-Qaradawi 2001: 23). Qaradawi characterizes fiqh alaqalliyyat as a branch of jurisprudence similar to medical, economic, or political jurisprudence. Taha Jabir al-Alwani, Chair of the North America Fiqh Council in Virginia further delineates fiqh al-aqalliyyat as "a specific discipline which takes into account the relationship between the religious ruling and the conditions of the community and the location where it exists" and meant to apply "to a specific group of people living under particular conditions with special needs" (2003: 3). These two figures have variously been cited as the founders or fathers of fiqh al-aqalliyyat. Qaradawi and Alwani both participated in the founding of the European Council for Fatwa and Research, a private association of muftis who issue fatwas addressing the conditions of Muslims in Europe.

Although the phrase "fiqh al-aqalliyyat" is not common among Shi'i jurists, who tend to speak of figh al-mughtaribin (jurisprudence of immigrants) or even fiqh almahjar (jurisprudence of emigration) rather than fiqh al-aqalliyyat (jurisprudence of minorities), Shi'i scholars have also shown an increased interest in "writing Islamic laws for Muslims who have settled in non-Muslim countries" (Al-Hakim 2001, 7). Shavit's article contends that the late Shi'i Grand Ayatollah Muhammad Husayn Fadlallah (1935-2010) shares in the wasatiyya (moderate) socio-juridical approach to contemporary issues that Warren and Gilmore convincingly argue Qaradawi most poignantly represents. Like Qaradawi, the writings of not only Fadlallah but also to a considerable extent Grand Ayatollah 'Ali Sistani (1930-) demonstrate considerable consciousness of two facts about the present lived circumstance of the community of Muslims that forms their wider audience: (1) that the presence of religious, ethnic, and other minorities in Muslim-majority contexts has challenged conceptions of citizenship, community, and the state premised on an Islamic identity and (2) that the nearly one third of all Muslims living as minorities throughout the world face diverse and complex challenges as they attempt to maintain their Islamic identity while negotiating their immediate socio-political context. The experiences of Muslims as minorities and of Muslim-majorities attempting to grapple with minorities in their midst are connected by various transnational networks of communication, organization, and influence and by new thinking on the part of prominent intellectuals. While the spread and scattering of Muslims across the globe has diversified their lived experiences, as Peter Mandeville 
(2001, 2007) has argued, the existence of translocal forces has contributed to the emergence of a wider Muslim public sphere. Islamic thinkers who attempt to address "Muslim concerns" must do so with the realization that a significant portion of their community is grappling with issues particular to their experiences as minorities.

Translocality involves a social relationship that functions both with and beyond a local frame and ultimately both transcends and transforms local circumstances. What Bettina Graf says of Qaradawi strikes me as equally true of many Shi'i thinkers, such as Fadlallah and Sistani: "There is a clear starting point for his activities: without the basis of the location in Qatar his activities would not be conceivable, neither on an intellectual nor on an organisational and financial level. There are further places that are important hubs for his thoughts and actions, such as Egypt, Palestine, Iraq, Ireland, Britain and others, as is evident from his website. In this respect he could be described neither as a global nor as a Qatari scholar, but as a scholar whose authority is established translocally" (2007: 418-19).

Vit Sisler has argued that European Islam "emphasizes the role of the Self, the privatization of faith, and the increasing insistence on religion as a system of values and ethics" rather than religion as an inherited cultural legacy (2009: 56). In an incredibly comprehensive review of the literature up to 2006, Frank Peter observes that the "individualization" of religious beliefs has become a common theme among research on Islam in Europe (2006: 106). Sisler's claims go further than some in maintaining that "the normative content online shapes offline religious manifestations and practices" (2011: 1,137). A number of scholars have noted how fatwa generation has a bottom-up character. As Sisler argues, "it is the petitioners, not the muftis, who set the issues to be discussed" (2011: 1,153) on most of the websites set up to generate fatwas for Muslims living outside Muslim majority contexts.

But is it also the case that this individualization can be seen in Muslim majority contexts - or at least among the muftis who address the concerns of Muslims in both contexts? If so, this fact would seem to challenge the notion that the relation between Islam in Europe and Muslim practices and beliefs in the Middle East can be characterized by discontinuity, another theme Peter finds to be prevalent in the literature on European Islam (2006: 106). Too little attention has been paid to the other side of this relation: the impact of the engagement of 'ulama situated in Muslim majority contexts with a transnational umma and with the particular concerns of Muslims non-Muslim contexts on their more general thought and their advice to Muslims in their "home" context. Certainly, there is a bit of a "chicken and egg" problem with most research on the issue of influence. Do muftis offer views in figh al-aqalliyyat because they are more flexible, moderate, and liberal or do they become so by virtue of engagement with this dialogue with European Muslims and their particular circumstances and requirements? It is not clear that we will be able to determine the direction of the causal relation. In fact, it is most likely the influence moves in both directions, since so many of the jurists who write on minority issues interact with a global Islam. Though each of the articles presented here would seem to provide some evidence for the conclusion that the distance between the interlocutors in this global conversation provides necessary space for reconsideration of the contemporary exigencies "on the balance of Islam."

What is perhaps most surprising in Shavit's analysis is the way in which salafi thinkers, such as Saudi Arabia's grand Mufti, 'Abd al-'Aziz bin 'Abdallah Al alShaykh, arrive at strikingly similar conclusions to Wasati figures, such as Qaradawi 
and Fadlallah, about the permissibility of political participation in non-Islamic environments. Demonstrating the significance of translocality to even salafi thinking, Shavit argues that some salafi jurists found it in some ways easier to legitimized Muslims voting in Western countries because they had already legitimized voting in illegitimate political systems in Muslim majority contexts.

The contribution by Mara Leichtman well illustrates how Muslims in Senegal are influenced both by the significant Lebanese population living in Senegal and by the impact of the Iranian Revolution's historical success and spread of its ideology through various transnational Islamic organizations, such that one sees not only the conversion of a number of Senagalese to Shi' $i$ forms of Islam but also their reformulation of a more cosmopolitan ethics aimed at providing for the needs of their local community in a way that both makes up for the failure of the Senegalese state and provides a counter to foreign intervention. Translocality in Leichtman's analysis takes the character of a cosmopolitan autochthony, where foreign practices and cosmopolitan ideas are appropriated into local development projects and claims for belonging, marshalled in strategic ways that allow Sengalese Shi'is to bypass the authority of Sufi marabouts and assert political autochthony. The goal of this "intellectual endeavor," she argues, "is not to assimilate Senegalese Muslims into a global movement but rather to adapt Shi' $\mathrm{i}$ Islam to a local African context."

The extent to which such engagements with local and global can transform thinking over time is well illustrated in Warren and Gilmore's examination of Qaradawi's writings on citizenship. Paying particular attention to shifts in Qaradawi's thought after 2010, the authors demonstrate the ways in which modern ideas about citizenship have been reconciled with classical Islamic concepts and Qaradawi's thinking about the citizenship of Muslims living as minorities outside of Islamic world has influenced and been influenced by his analysis of the citizenship state of non-Muslims in Muslim majority contexts. As Warren and Gilmore demonstrate, Qaradawi does not, in the end, appropriate liberal notions, but expands and rethinks Islamic notions in a more inclusive direction.

Warren and Gilmore remain both well attentive to the limits of Qaradawi's thinking on citizenship at the same time that they offer somewhat optimistic conclusions about the resiliency of his formulation, particularly for the way in which his understanding of muwatina at once decenters Western ideas and responds to local needs and thus "may yet prove more applicable, and indeed durable," in contexts where secularism still remains suspect. Yet, Ahmad Najib Burhani's study of Indonesia's Ahmadiyya community demonstrates the continuity between classical and contemporary juridical treatments of Muslims who are thought to have deviated substantially from orthodox beliefs. Examining Abu Hamid Muhammad al-Ghazali's framework for distinguishing Muslims from non-Muslims, Burhani finds that only the category of Muslims who deviate from what al-Ghazali deems acceptable interpretations of Islam can apply to the Ahmadiyya. However, it is for those in this category, occupied by the Batiniyya and the philosophers in al-Ghazali's time, that al-Ghazali expresses particular concern and marshals his harshest critique. They form, in Burhani's reading of al-Ghazali, a proximate threat, "located just inside the border of the outer limits of Islam." Burhani locates parallel between al-Ghazali's mode of argumentation and fatwas issued over the past century by five international and Indonesian organizations. Burhani's analysis puts forth the negative exception that may prove the rule of the productive space of the 
translocal encounter between minorities in Islam and Muslims as minorities. According to his analysis, it is precisely the proximity - that is the Ahmadiyya's insistence on their Islamic character coupled with orthodox Islam's rendering of this community as deviant based not based on outright rejection of Islam but on their heterodoxy - that renders the Ahmadiyya an exigent-threat and denies them the protections granted by some of the same jurists to non-Muslims.

\section{References}

Abu-Salieh, S. A. A. (1996). The Islamic concept of migration. International Migration Review, 30(1), $37-57$. Al-Alwani, T. J. (2003). Towards a fiqh for minorities: some basic reflections. London: The International Institute of Islamic Thought.

Al-Hakim, A. H. (2001). A code of practice for Muslims in the West in accordance with the edicts of His Eminence Grand Ayatullah al-Sayyid Ali al-Husaini as-Seestani. London: Imam Ali Foundation.

Al-Qaradawi, Y. (2001). Fi fiqh al-aqalliyyat al-muslima. Cairo: Dar al-Shuruq.

Graf, B. (2007). Sheikh Yusuf al-Qaradawi in cyberspace. Die Welt des Islams, 47(3-4), 403-421.

Mandeville, P. (2001). Transnational Muslim politics: reimagining the Umma. New York: Routledge.

Mandeville, P. (2007). Global political Islam. New York: Routledge.

Peter, F. (2006). Review essay: individualization and religious authority in Western European Islam. Islam and Christian-Muslim Relations, 17(1), 105-118.

Sisler, V. (2009). European courts' authority contested? The case of marriage and divorce Fatwas on-line. Masaryk University Journal of Law and Technology, 3(1), 51-78.

Sisler, V. (2011). Cyber counsellors: online Fatwas, arbitration tribunals and the construction of muslim identity in the UK. Information, Communication and Society, 14(8), 1136-1159. 